\title{
Wenchuan Earthquake Surface Fault Rupture and Disaster: A Lesson on Seismic Hazard Assessment and Mitigation
}

\author{
Yi Du, ${ }^{1}$ Furen Xie, ${ }^{1}$ and Zhenming Wang ${ }^{2}$ \\ ${ }^{1}$ Institute of Crustal Dynamics, China Earthquake Administration, Beijing 100085, China \\ ${ }^{2}$ Kentucky Geological Survey, University of Kentucky, Lexington, KY 40506-0107, USA
}

Correspondence should be addressed to Yi Du, yidu.uk@gmail.com

Received 4 May 2012; Revised 25 July 2012; Accepted 4 August 2012

Academic Editor: Vladimir G. Kossobokov

Copyright ( 2012 Yi Du et al. This is an open access article distributed under the Creative Commons Attribution License, which permits unrestricted use, distribution, and reproduction in any medium, provided the original work is properly cited.

\begin{abstract}
The $M_{s}$ 8.0 Wenchuan earthquake occurred along the Longmenshan Faults in China and was a great disaster. Most of the damage and casualties during the quake were concentrated along surface rupture zones: the 240-km-long Beichuan-Yingxiu Fault and the 70-km-long Jiangyou-Guanxian Fault. Although the Longmenshan Faults are well known and studied, the surface Fault ruptures were not considered in mitigation planning, and the associated ground-motion hazard was therefore underestimated. Not considering Fault rupture and underestimating ground-motion hazard contributed to the disastrous effects of the earthquake. The lesson from the Wenchuan earthquake disaster is that the fault rupture hazard must be assessed and considered in mitigation. Furthermore, the deterministic approach is more appropriate for fault rupture hazard assessment than the probabilistic approach.
\end{abstract}

\section{Introduction}

On May 12, 2008, the $M_{s} 8.0$ Wenchuan earthquake in China caused many houses to collapse and huge casualties. It occurred in the Longmenshan thrust nappe tectonic zone, the junction of the Bayan Har block on the Tibetan Plateau and the South China block in eastern China (Figure 1). The zone consisted of a front range fault (Jiangyou-Guanxian Fault) a central fault (Beichuan-Yingxiu Fault), a back range fault (Wenchuan-Maoxian Fault), and their related folds (Figure 1). The zone has experienced strong tectonic activity and intensively active faults, making it a strong earthquakeprone area since it is not only the junction of the Bayan Har and South China blocks, but also a part of the north-south seismic tectonic zones on the Chinese mainland. The MS 8.0 Wenchuan earthquake was the result of the Longmenshan thrust nappe pushing southeast, accompanied by clockwise shearing.

The Wenchuan earthquake was a great disaster, causing more than $\$ 110$ billion in damage and killing about 90,000 people [1]. There were many reasons for this disaster, such as large magnitude $\left(\mathrm{M}_{\mathrm{s}} 8.0\right)$, high mountains and steep slopes, and dense population. However, one of the main reasons was that the seismic hazards, surface fault rupture, and ground motion were either underestimated or ignored.
Although the Longmenshan Faults and the associated seismicity are well known and studied (Figure 1), the surface fault rupture hazard was not considered in any mitigation planning. The previously estimated ground motion hazard (i.e., peak ground acceleration with 10 percent probability of exceedance in 50 years) for building seismic design was only 0.1 to $0.15 \mathrm{~g}$ PGA (Figure 2). In other words, the seismic hazards in the area were underestimated, which led to the communities being unprepared for the hazards.

\section{Characteristics of Earthquake Surface Rupture}

The $M_{s}$ 8.0 Wenchuan earthquake produced two northwestdipping surface ruptures on the Longmenshan thrust nappe tectonic zone on the eastern edge of the Tibetan Plateau: the Beichuan-Yingxiu rupture and the Guanxian-Jiangyou rupture, both imbricate thrust faults that produced earthquake scarps, falling water, cracks, and other surface ruptures running north along the central fault to regions like Qingchuan and Muyu, forming a continuous, distinct surface rupture zone. The Beichuan-Yingxiu surface rupture was about $240 \mathrm{~km}$ long, characterized by dextral slip thrusting. A surface rupture near Leigu in Beichuan had a maximum 


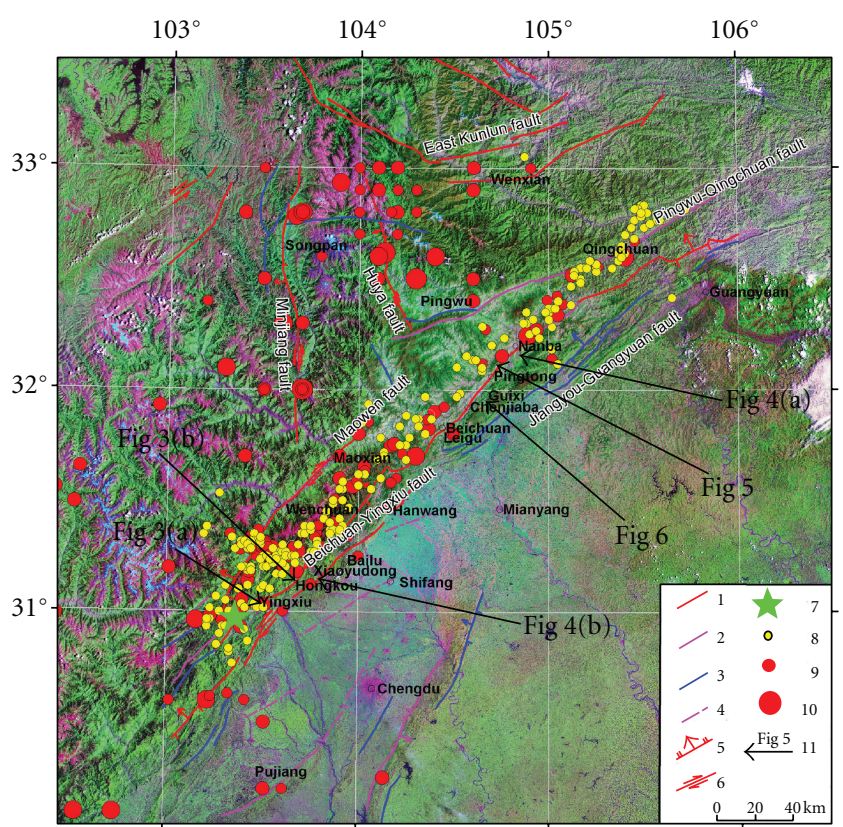

Figure 1: Seismotectonics and distribution of historical earthquakes of the Wenchuan area. (1) Holocene active fault. (2) Late Pleistocene active fault. (3) Early and middle Pleistocene active fault. (4) Buried active fault. (5) Normal fault. (6) Strike-slip fault. (7) Ms 8.0 earthquake surface ruptures. (8) Epicenter of the Ms 8.0 earthquake. (9) Historical earthquakes ranging from $\mathrm{M}_{\mathrm{s}} 4.7$ to 5.0. (10) Historical earthquakes ranging from $M_{s} 4.7$ to 5.0. (11) Figure location.

vertical displacement of $6.2 \mathrm{~m}$ and a dextral slip displacement of $4.9 \mathrm{~m} \mathrm{[2]}$. The Guanxian-Jiangyou surface rupture was about $90 \mathrm{~km}$ long and characterized by pure thrusting. In the village of Luoyang, maximum vertical displacement was $3.5 \mathrm{~m}$ and horizontal displacement was $1.9 \mathrm{~m}$. Furthermore, west of the two above-mentioned rupture zones, a $6-\mathrm{km}$ long, northwest-trending rupture zone in Xiaoyudong was characterized by sinistral-slip thrusting, resulting in one of the most complex structures in the recent devastating earthquakes [1]. In the back range fault, we found no surface rupture, but many secondary geologic disasters such as landslides and avalanches (Table 1).

Overall, the Beichuan-Yingxiu surface rupture was distinctly segmented, roughly bounded by the region from Leigu to Beichuan. Its southwest segment was characterized by pure thrusting with smaller horizontal displacement; its northeastern segment was characterized by slip thrusting with roughly equal vertical and horizontal displacement or slightly larger horizontal displacement. The GuanxianJiangyou rupture started at Cifeng in the south and stretched northeast, passing Bailu, Jiulong, Hanwang, and Zhishui, its total length being about $70 \mathrm{~km}$. This surface rupture was characterized by a reverse fault, with larger horizontal displacement only in some individual segments.

Tectonic stress tensor inversion from the earthquake fault slip data showed that in the tectonic stress field of today's Longmenshan in its latest tectonic period, the maximum principal compressive stress direction is 76 to $121^{\circ}$ [3]. The Longmenshan Fault Zone, under nearly east-west-trending

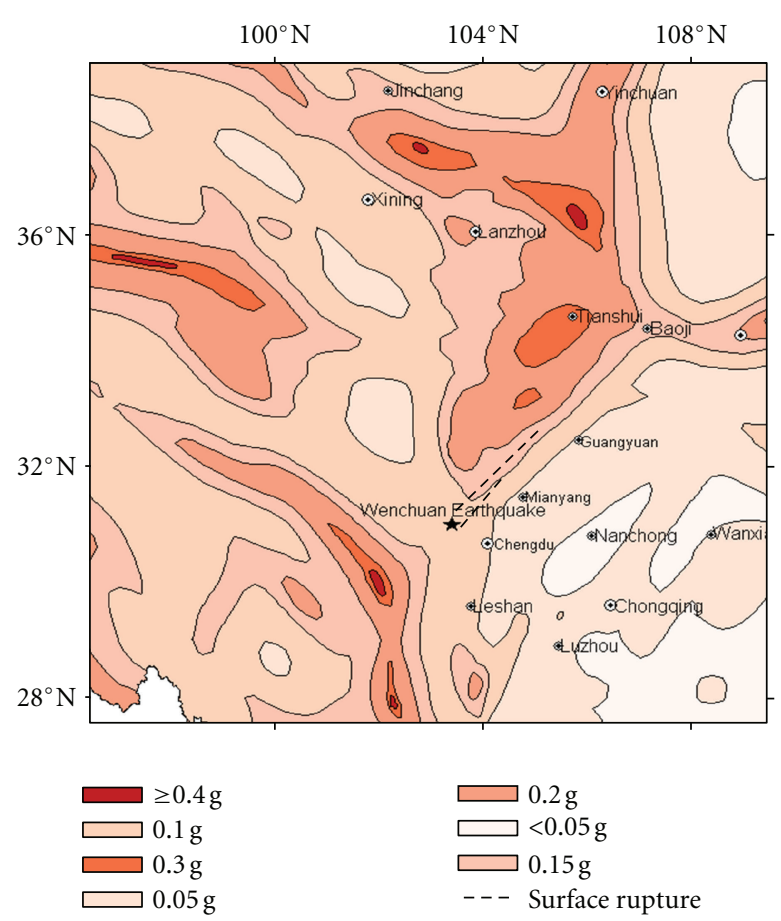

FIGURE 2: Chinese national design peak ground acceleration for the Wenchuan area [4].

squeezing of the regional tectonic stress field, generally shows a kind of thrust movement. In the Beichuan-Yingxiu surface rupture, the angle between the principal compressive stress direction from the earthquake fault slip data inversion and the fault strike is between 45 and $70^{\circ}$, relatively larger. In the north segment of the Beichuan rupture, the angle between the principal compressive stress direction and the strike fault is generally between 20 and $40^{\circ}$, relatively smaller. Because of changes in the principal compressive stress direction and the fault geometry features, fault movement patterns changed: the Yingxiu-Beichuan Fault was characterized by thrusting movement with generally smaller strike-slip, while in the north segment of Beichuan the upward thrusting movement was accompanied by significant strike-slip displacement, with the slip component greater than the vertical component. This demonstrates that in different segments of the same surface rupture, and influenced by changes in its own geometric characteristics and tectonic stress field, the fault activity obviously changed its characteristics.

\section{Damage by Surface Ruptures}

3.1. Thrust Surface Rupture and Its Effects. Near Yingxiu along national highway 213, multiple seismic scarps were observed, among which the most deformed had a vertical displacement of about $2.0 \mathrm{~m}$ and a horizontal displacement of only about $0.6 \mathrm{~m}$ (Figure 3(a)). In Bajiaomiao in Hongkou, at the leading edge of the first-order terrace, the earthquake produced a $4.3 \mathrm{~m}$ fault scarp, with a new grayish black section trending $40^{\circ}$ northeast and dipping $76^{\circ}$ northwest, on which a set of scratches were produced 
TABLE 1: The inverted result of tectonic stress tensor of each measuring point.

\begin{tabular}{|c|c|c|c|c|c|c|c|c|c|c|c|}
\hline \multirow{2}{*}{ No } & \multicolumn{3}{|c|}{ Location } & \multirow{2}{*}{ Lattitude $\left({ }^{\circ}\right)$} & \multirow{2}{*}{ quantity } & \multicolumn{2}{|l|}{$\sigma_{1}$} & \multicolumn{2}{|l|}{$\sigma_{2}$} & \multicolumn{2}{|l|}{$\sigma_{3}$} \\
\hline & lon & lat & site & & & direction & $\operatorname{dip}$ & direction & $\operatorname{dip}$ & direction & $\operatorname{dip}$ \\
\hline BDT & $105^{\circ} 32^{\prime} 25.6^{\prime \prime}$ & $32^{\circ} 34^{\prime} 17.9^{\prime \prime}$ & Zhuya & $60 \sim 80 / \mathrm{N} \angle 30 \sim 80$ & 27 & 97 & 8 & 203 & 64 & 3 & 24 \\
\hline $\mathrm{MDB}$ & $103^{\circ} 34^{\prime} 9.1^{\prime \prime}$ & $31^{\circ} 2^{\prime} 49.5^{\prime \prime}$ & Maxi & $90 \sim 110 / \mathrm{N} \angle 60 \sim 70$ & 30 & 264 & 15 & 359 & 20 & 138 & 65 \\
\hline MJK & $105^{\circ} 26^{\prime} 39.1^{\prime \prime}$ & $32^{\circ} 39^{\prime} 57.7^{\prime \prime}$ & Shazhou & $25 \sim 80 / \mathrm{NW} \angle 44 \sim 80$ & 44 & 271 & 17 & 173 & 23 & 33 & 61 \\
\hline MHK & $103^{\circ} 54^{\prime} 58.9^{\prime \prime}$ & $31^{\circ} 12^{\prime} 53.1^{\prime \prime}$ & Bailu & $20 \sim 50 / S \angle 50 \sim 85$ & 51 & 102 & 1 & 12 & 37 & 192 & 53 \\
\hline MLL & $104^{\circ} 9^{\prime} 39.1^{\prime \prime}$ & $31^{\circ} 27^{\prime} 37.7^{\prime \prime}$ & Hanwang & $50 \sim 110 / \mathrm{W} \angle 55 \sim 75$ & 40 & 121 & 4 & 30 & 14 & 227 & 75 \\
\hline MYD & $105^{\circ} 24^{\prime} 47.2^{\prime \prime}$ & $32^{\circ} 38^{\prime} 31.9^{\prime \prime}$ & Muyv & $65 \sim 70 / \mathrm{S}, \mathrm{W} \angle 78 \sim 50$ & 37 & 287 & 3 & 195 & 23 & 25 & 67 \\
\hline PTN & $104^{\circ} 42^{\prime} 56^{\prime \prime}$ & $32^{\circ} 5^{\prime} 2.8^{\prime \prime}$ & Pingtong & $48 \sim 61 / \mathrm{N} \angle 35 \sim 50$ & 53 & 79 & 17 & 173 & 12 & 296 & 69 \\
\hline MWC & $103^{\circ} 41^{\prime} 30.5^{\prime \prime}$ & $31^{\circ} 8^{\prime} 43.1^{\prime \prime}$ & Hongkou & $30 \sim 50 / \mathrm{W} \angle 65 \sim 85$ & 29 & 271 & 10 & 5 & 21 & 158 & 66 \\
\hline
\end{tabular}

with a 75 to $80^{\circ}$ west pitch, indicating that the fault's basic movement pattern was thrusting with smaller strike-slip (Figure 3(b)).

At the Bailu Middle School, we observed a surface rupture trending $40^{\circ}$ northeast, whose thrusting movement caused the cement boards to overlap or plump up, forming a $1.5-\mathrm{m}$-long scarp. Classrooms on the hanging wall and flat wall were damaged to varying degrees, but did not collapse, whereas the buildings on the distant fault had already collapsed. In Liangfengya of the town of Leigu, we observed a surface rupture zone trending 20 to $30^{\circ}$ along the $\mathrm{S} 105$ Highway, forming a fault up to $4.5 \mathrm{~m}$ in length, showing a strong thrust characteristic.

3.2. Strike-Slip Surface Rupture and Its Effects. Surface dislocations near Nanba were mainly ruptures, dammed ponds, and ground fissures along faults. East of Nanba, a fault trending 35 to $50^{\circ}$ northeast cut through rivers and roads, forming an obvious surface rupture zone with a vertical displacement of about $1.5 \mathrm{~m}$ and a dextral horizontal displacement of about $2.5 \mathrm{~m}$ (Figure 4(a)). Small sag-ponds were formed on the floodplain by a reverse fault with about 1 to $1.5 \mathrm{~m}$ of vertical displacement. Near the north side of the dammed pond, a dextral displacement of about $3.0 \mathrm{~m}$ was observed. Buildings within $500 \mathrm{~m}$ of the rupture zone were severely damaged, mostly collapsed. The houses on top of the rupture were completely destroyed. Although some houses did not collapse, they were still unsafe for habitation. North of the Nanba Fault, houses on the footwall side suffered an overall tilt or twist because of the fault's dextral movement.

There were very obvious surface ruptures in towns such as Hanwang, Jiulong, and Bailu. In the town of Hanwang, the fault cut through roads and rivers, forming waterfalls in the river, and it produced on the road and floodplain a scarp about 1.5 to $2 \mathrm{~m}$ high, dislocating all the roads on both sides of the river. Near Xiaoyudong, we observed a surface rupture fault trending 290 to $320^{\circ}$, which dislocated roads and farmlands, forming a scarp about 1.5 to $2.5 \mathrm{~m}$ high with a sinistral horizontal movement of 1 to $3 \mathrm{~m}$ (Figure 4(b)). The eastern part of the Xiaoyudong Bridge completely collapsed as a result of sinistral thrusting, whereas the western part of the bridge, located on the hanging wall, was distorted and wavy, making the entire bridge completely unusable.
3.3. Ground Fissures Caused by Surface Fault Rupture. The earthquake seriously destroyed the ground and the mountain. Obvious ground fissures could be seen in many places. In some places, the fissures exceeded $30 \mathrm{~cm}$. Buildings in zones with dense fissures suffered significant damage, even collapse. Fissures were not only related to the earthquake's own characteristics, but also to local geologic structure. The earthquake produced a great deal of ground fissures, not only near the surface rupture fault, but also 1 to $2 \mathrm{~km}$ away from it; in some regions dense ground fissures were observed. Along the highway east of Muyu, the earthquake produced a surface rupture fault trending 50 to $60^{\circ}$ northeast, forming a scarp about $0.2 \mathrm{~m}$ high, on whose hanging wall the earthquake produced a nearly vertical tensile crack trending 80 to $110^{\circ}$ (Figure 5).

In towns such as Guixi and Pingtong, the earthquake also produced scarps. Roads, fields, rivers, and aquariums were all dislocated and destroyed; horizontal and vertical dislocation measured $1.9 \mathrm{~m}$ and $2.0 \mathrm{~m}$, respectively. Along Pingtong and Taisong, far away from the fault, the cement boards on the highway were still arched or overlapped as a result of strong squeezing of the fault with a dextral dislocation of about 10 to $30 \mathrm{~cm}$. Meanwhile, on both sides of the damaged road, we could see a dense distribution of many tensile cracks trending nearly east-with, with widths ranging from a few meters to tens of meters, causing huge damage to the roadbed of the highway.

In Hanwang, Jiulong, and Bailu, surface ruptures were observed. The fault cut through roads and rivers, and produced scarps of about 1.5 to $2 \mathrm{~m}$ high along the road and on the floodplain, forming waterfalls in the river. On the hanging wall sides, a set of south-dipping cracks trending 30 to $50^{\circ}$ and 20 to $35 \mathrm{~cm}$ wide was also observed. As shown in Figure 5, the cement pavement was plumped up, forming an overlapped part of about $1.7 \mathrm{~m}$ long, $\pm 0.2 \mathrm{~m}$. This $20 \mathrm{~m}$ long cement highway showed traction phenomenon, and the combined part of the cement pavement was broad in the south and narrow in the north. Just a little away from the fault and along the rupture hanging wall, a group of tensile cracks trending 70 to $100^{\circ}$ was also observed.

In Bailu, the earthquake produced a fault trending $40^{\circ}$ northeast, which cut through the Laojie River, forming a waterfall 2 to $2.5 \mathrm{~m}$ high. On the highway and hillside in northeast Bailu, the earthquake produced many nearly 


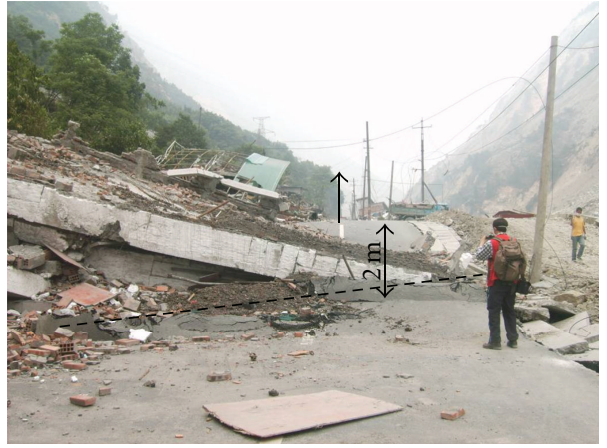

(a)

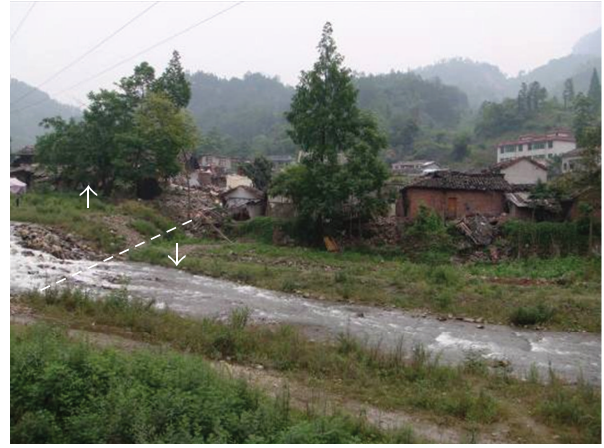

(b)

FIgUre 3: Thrust surface rupture and damage. The more severe damage is on the hanging wall.

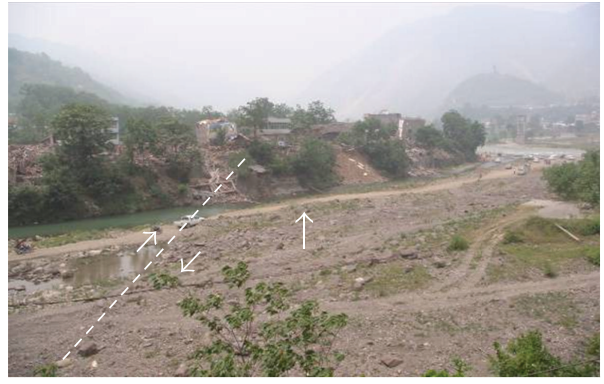

(a)

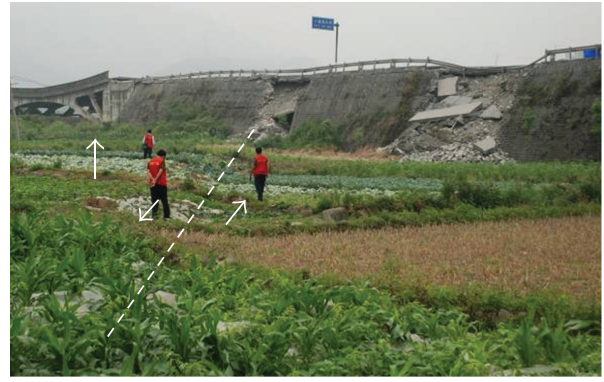

(b)

FIgURE 4: Strike-slip movement with thrust surface rupture.

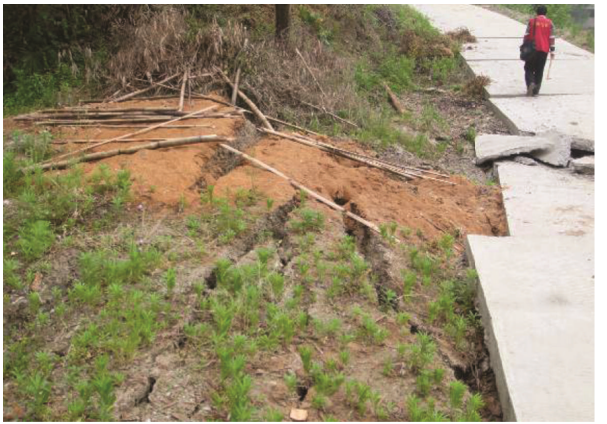

FIGURE 5: Ground fissures near a surface rupture fault.

vertical tension cracks trending 90 to $100^{\circ}$, with lengths exceeding $500 \mathrm{~m}$, damaging the roads.

\subsection{Fault Rupture-Induced Secondary Geologic Hazards.} Along the surface rupture zones, the earthquake produced a great many secondary geologic hazards, including collapses, landslides, and mudslides, which caused huge casualties and property losses. In some areas, such as Beichuan and Yingxiu, casualties and property losses caused by secondary geologic hazards were far greater than those caused by the earthquake directly.

A landslide on the northwest side of the village of Fenghuang was formed on the central fault hanging wall, burying dozens of farmhouses (Figure 6). The leading edge

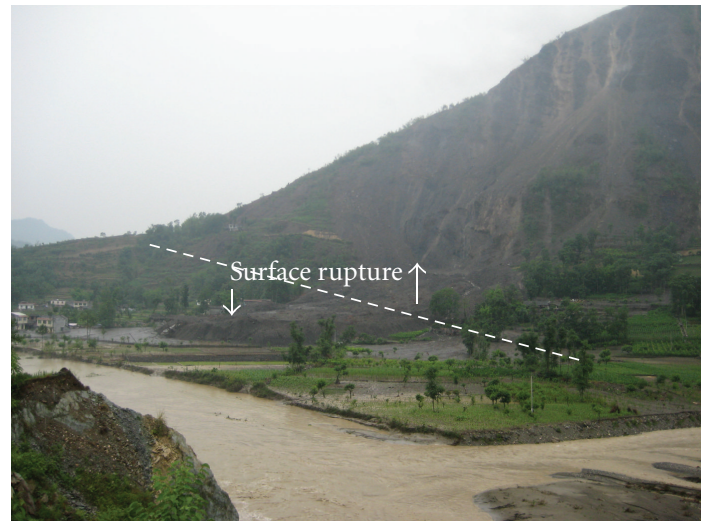

FIGURE 6: Secondary geologic hazards caused by fault ruptures.

of the landslide reached the other side of the river, forming a dammed lake. On the west side of Fenghuang, we could see that the surface rupture zone formed a scarp both in the river bed and on the first-order terrace, with the landslide body falling from the hanging wall and covering up the fault scarp.

The Chenjiaba landslide formed on the central fault hanging wall on the northwest side of Chenjiaba. The landslide fell through the ruptured valley, with its leading edge reaching the other side of the lake, forming a dammed lake. The north part of the landslide thrust into Chenjiaba, resulting in severe building damage and dozens of deaths. In Hanwang, the fault was about $10 \mathrm{~m}$ away from the bridge. 
The bridge head was severely damaged and the bridge deck was distorted and arched, but the bridge can still be used. On the fault hanging wall, we could see many partial collapses in the mountain and blocked roads.

\section{Discussion}

The Wenchuan earthquake demonstrated that hazards from fault surface rupture, as well as from ground motion, were not adequately considered in mitigation planning, such as the building code. No set-back or other measure was in place for mitigation of surface fault rupture in the Wenchuan area. As shown in Figure 2, the design peak ground acceleration [4] was quite low, only 0.1 to $0.15 \mathrm{~g}$, in the Wenchuan area. Thus, we must discuss how seismic hazards, ground motion and surface rupture in particular, are assessed and used.

Although several methods are being used to assess ground motion and fault rupture hazard, they can be separated into two general categories: probabilistic and deterministic. Probabilistic methods are intended to determine the probability that ground motion or fault rupture will exceed a given level. For example, probabilistic seismic hazard analysis (PSHA) was intended to estimate the annual probability of exceedance (i.e., the probability of exceedance in 1 year) for a given ground-motion level [5]. Similarly, probabilistic fault rupture hazard analysis (PFDHA) was intended to estimate the annual probability of exceedance for a given displacement [6]. PFDHS was essentially developed in the same way as PSHA [6]. In contrast, deterministic methods are intended to determine a ground motion with a level of uncertainty (e.g., 50th percentile [median] or 84th percentile) from one or a set of earthquake scenarios. For example, deterministic seismic hazard analysis (DSHA) is used to determine the median or certain percentile (e.g., 84th percentile) of ground motion from a single earthquake or set of earthquakes $[7,8]$. In other words, probabilistic methods emphasize the probability of occurrence (statistical characteristics) for a given hazard (i.e., ground motion or displacement), whereas deterministic methods emphasize the ground motion or displacement (physical characteristics) at a site.

Although PSHA has been widely used in seismic hazard assessment, recent studies have found that it has intrinsic problems $[9,10]$. In particular, PSHA contains a mathematical error: equating a dimensionless quantity (i.e., the annual probability of exceedance-the probability of exceedance in 1 year) to a dimensional quantity with the unit of per year (i.e., the annual frequency or rate of exceedance) [10]. This mathematical error led to the so-called ergodic assumption: "PSHA treats that spatial uncertainty of ground motions as an uncertainty over time at a single point" [11, page 19]. Thus, the results from PSHA are artifacts and the use of PSHA is problematic $[10,12]$. As shown in Figure 2, the peak ground acceleration with 10 percent probability of exceedance in 50 years in the Wenchuan earthquake epicentral area, derived from PSHA [4], was only about 0.1 to $0.15 \mathrm{~g}$, which was significantly lower than the observations, about 1.0g PGA [13]. Seismic hazards were also underestimated by PSHA for recent earthquakes, such as the 2009 L'Aquila earthquake (M6.3), 2010 Haiti earthquake (M7.1), 2011 Japan earthquake (M9.0), and 2011 Christchurch earthquake.

Although DSHA is not the favored current practice, it has advantages, such as (1) it has a clear physical and statistical meaning and (2) it is easily understood by earth scientists, engineers, and others. The ground motion specified for bridge design in California is actually determined by the deterministic ground motion from the maximum credible earthquake [14] and the ground motion for building seismic design in coastal California is capped by a deterministic ground motion close to major fault sources [15]. Wang and others [16] used DSHA to develop ground-motion hazard maps for bridge and highway seismic design in Kentucky. Another advantage is that DSHA can utilize ground-motion simulation [17-19]. Thus, DSHA is more appropriate than PSHA for seismic hazard assessment.

Similar to using PSHA for ground-motion hazard assessment, PFDHA is not appropriate for fault rupture hazard assessment. Abrahamson [20] showed that the ergodic assumption is not reasonable for surface fault rupture models. The deterministic method is more widely used. For example, the surface rupture design parameters for the Trans-Alaska Pipeline crossing the Denali Fault were determined deterministically [21]. The Trans-Alaska Pipeline performed well during the 2002 Denali earthquake (M7.9), which produced $5.8 \mathrm{~m}$ of right-lateral and $1.2 \mathrm{~m}$ of vertical slip at the pipeline crossing [21].

\section{Conclusions}

The surface fault ruptures were a controlling factor on the patterns and severity of damage during the Wenchuan earthquake: (1) most of the damage was concentrated along surface rupture zones and (2) the damage was more severe on the hanging wall than on the footwall. Different fault segments were found to have different geometric characteristics and different tectonic stress environments. Active faults and associated surface characteristics must therefore be investigated. Moreover, incorporating the results of active fault investigations into a hazard assessment of a surface fault rupture, as well as an assessment of ground-motion hazard, is vitally important.

The ground-motion hazard in the Wenchuan epicentral area was significantly underestimated by PSHA, which might have contributed to the great disaster. Surface fault rupture hazard is more appropriately determined by a deterministic approach. Field investigation showed that the width of most surface ruptures was less than $40 \mathrm{~m}$. We therefore recommend a $40 \mathrm{~m}$ setback from the fault for construction in Wenchuan area.

\section{References}

[1] X. W. Xu, X. Z. Wen, J. Q. Ye et al., "The MS8.0 Wenchuan earthquake surface ruptures and its seismogenic structure," Seismology and Geology, vol. 30, no. 3, pp. 597-629, 2008.

[2] Y. K. Ran, X. Shi, H. Wang et al., "The maximum coseismic vertical surface displacement and surface deformation pattern 
accompanying the Ms 8.0 Wenchuan earthquake," Chinese Science Bulletin, vol. 55, no. 9, pp. 841-850, 2010.

[3] Y. Du, F. R. Xie, X. L. Zhang, and Z. J. Jing, "The mechanics of fault slip of Ms8.0 Wenchuan earthquake," Chinese Journal of Geophysics, vol. 52, no. 2, pp. 464-473, 2009 (Chinese).

[4] People's Republic of China National Standard, Seismic Ground Motion Parameter Zonation Map of China, China Standard Press, 2001, GB 18306-2001.

[5] C. A. Cornell, "Engineering seismic risk analysis," Bulletin of the Seismological Society of America, vol. 58, pp. 1583-1606, 1968.

[6] K. J. Coppersmith and R. R. Youngs, "Data needs for probabilistic fault displacement hazard analysis," Journal of Geodynamics, vol. 29, no. 3-5, pp. 329-343, 2000.

[7] E. L. Krinitzsky, "Deterministic versus probabilistic seismic hazard analysis for critical structures," Engineering Geology, vol. 40, no. 1-2, pp. 1-7, 1995.

[8] E. L. Krinitzsky, "How to obtain earthquake ground motions for engineering design," Engineering Geology, vol. 65, no. 1, pp. $1-16,2002$.

[9] Z. Wang, "Comment on "sigma: issues, insights, and challenges" by Fleur O. Strasser, Norman A. Abrahamson, and Julian J. Bommer," Seismological Research Letters, vol. 80, pp. 491-493, 2009.

[10] Z. Wang, "Seismic hazard assessment: issues and alternatives," Pure and Applied Geophysics, vol. 168, no. 1-2, pp. 11-25, 2011.

[11] J. G. Anderson and J. N. Brune, "Probabilistic seismic hazard analysis without the ergodic assumption," Seismological Research Letters, vol. 70, no. 1, pp. 19-28, 1999.

[12] Z. Wang and C. Cobb, "A critque of probablistic versus deterministic seismic hazard analysis with special reference to the new mardid seismic zone," in Recent Advances in North American Paleoseismology and Neotectonics East of Rockies, R. Cox, O. Boyd, and M. Tuttle, Eds., Geological Society of America Special Paper.

[13] Z. Wang and M. Lu, "A short note on ground-motion recordings from the M7. 9 Wenchuan, China, earthquake and ground-motion prediction equations in the central and eastern United States," Seismological Research Letters, vol. 82, pp. 731-733, 2011.

[14] L. Mualchin, "History of modern earthquake hazard mapping and assessment in California using a deterministic or scenario approach," Pure and Applied Geophysics, vol. 168, no. 3-4, pp. 383-407, 2011.

[15] Building Seismic Safety Council, NEHRP Recommended Provisions for Seismic Regulations for New Buildings, Federal Emergency Management Agency, 2009, FEMA P-750.

[16] Z. Wang, E. W. Woolery, B. Shi, and I. E. Harik, "Seismic hazard maps and time histories from earthquakes affecting Kentucky," Research Report KTC-07-06/SPR246-02-6F, University of Kentucky, Kentucky Transportation Center, 2007.

[17] F. R. Xie, X. F. Cui, J. T. Zhao, Q. C. Chen, and H. Li, "Regional division of the recent tectonic stress field in China and adjacent areas," Acta Geophysica Sinica, vol. 47, no. 4, pp. 654-662, 2004.

[18] K. Irikura and H. Miyake, "Recipe for predicting strong ground motion from crustal earthquake scenarios," Pure and Applied Geophysics, vol. 168, no. 1-2, pp. 85-104, 2011.

[19] E. Zuccolo, F. Vaccari, A. Peresan, and G. F. Panza, "Neodeterministic and probabilistic seismic hazard assessments: a comparison over the italian territory," Pure and Applied Geophysics, vol. 168, no. 1-2, pp. 69-83, 2011.
[20] N. Abrahamson, "Non-ergodic models for probabilistic fault rupture hazard," in Seismological Society of America Annual Meeting, San Diego, Calif, USA, April 2012.

[21] G. Carver, G. Plafker, M. Metz et al., "Surface rupture on the Denali Fault interpreted from tree damage during the 1912 Delta river Mw 7.2-7.4 earthquake: implications for the 2002 Denali Fault earthquake slip distribution," Bulletin of the Seismological Society of America, vol. 94, no. 6, pp. S58-S71, 2004. 

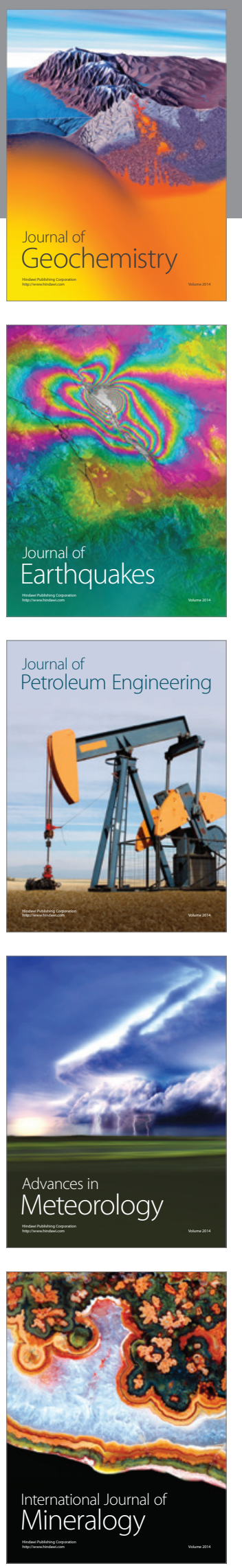
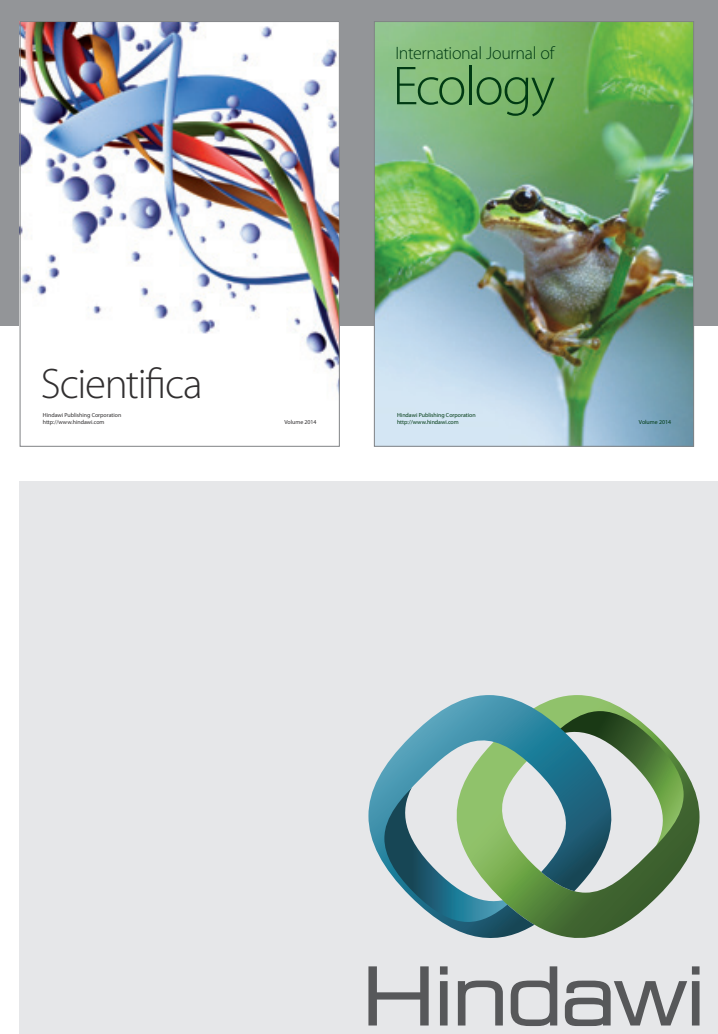

Submit your manuscripts at http://www.hindawi.com
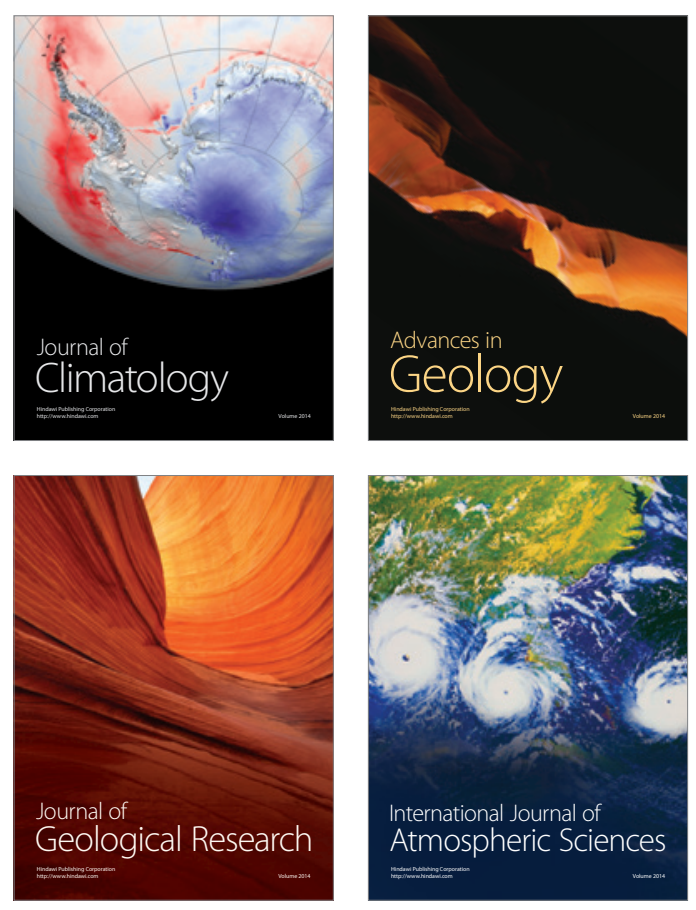
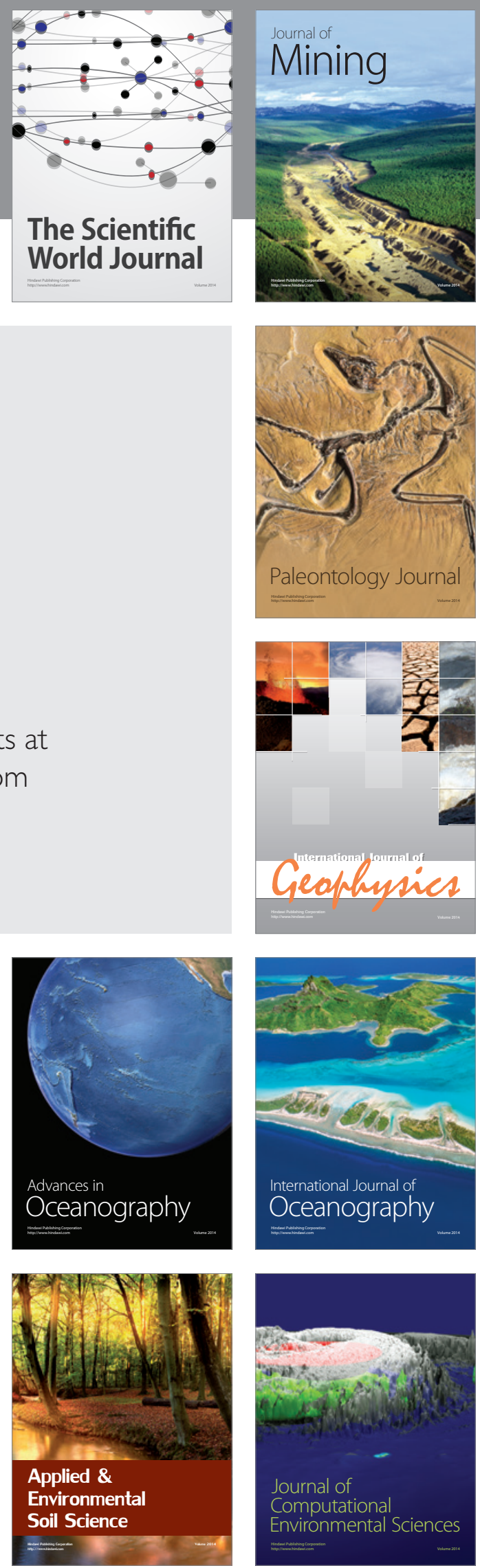